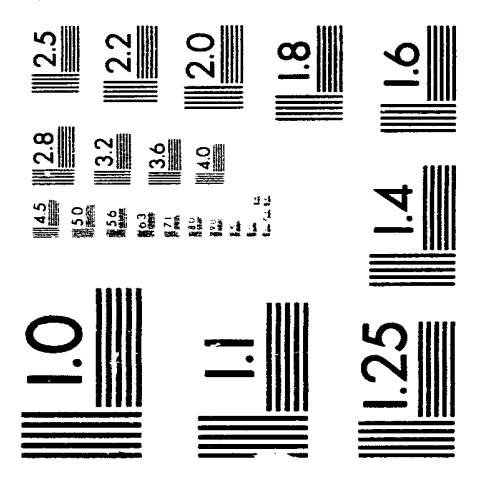



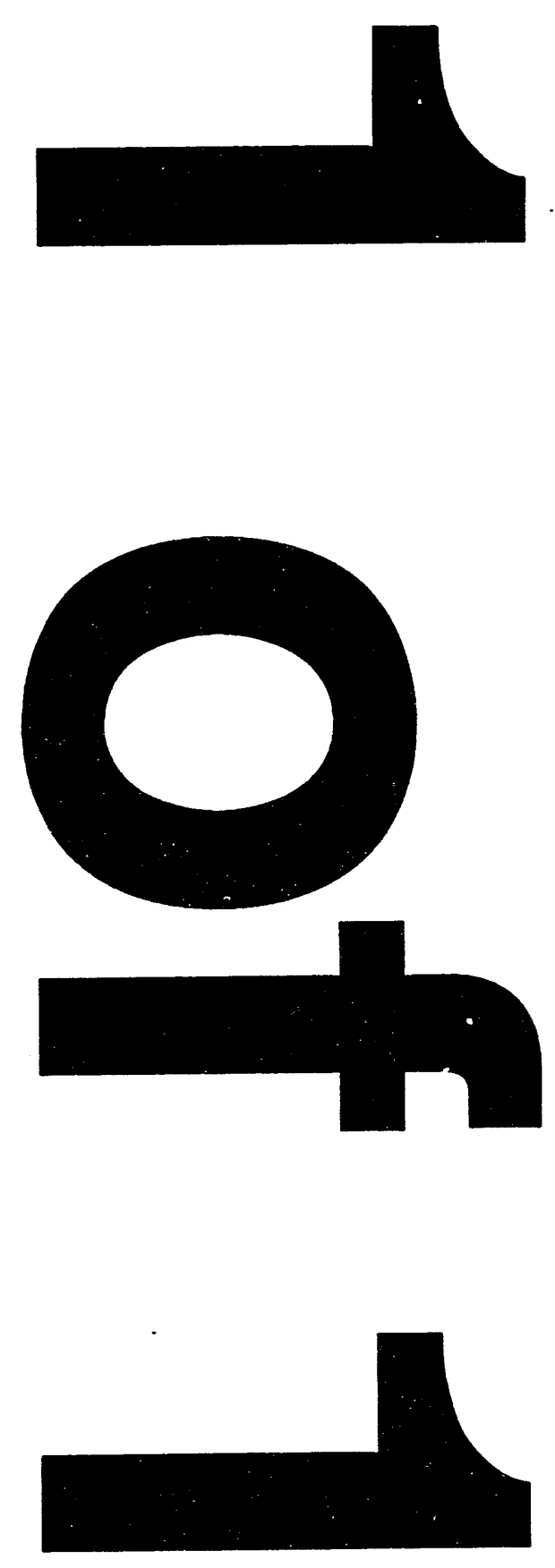


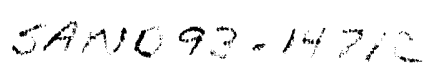

\title{
MICROSTRUCTURES OF Si SURFACE LAYERS IMPLANTED WITH Cu
}

\author{
DAVID M. FOLLSTAEDT AND SAMUEL M. MYERS
}

Semiconductor Physics Dept., Sandia National Laboratories, Albuquerque, NM 87185-1056

\begin{abstract}
The microstructures of $\mathrm{Si}$ ion-implanted with $\mathrm{Cu}$ have been characterized by TEM after annealing. For 1.2 at.\%, the $\mathrm{Cu}$ is trapped at planar defects, but for 10 at.\%, $\eta-\mathrm{Cu}_{3} \mathrm{Si}$ forms and $\mathrm{Cu}$ diffuses at its equilibrium solubility. These observations allow proper evaluation of the binding energies of $\mathrm{Cu}$ to previously formed internal cavities $(2.2 \mathrm{eV})$ and $\eta-\mathrm{Cu}_{3} \mathrm{Si}(1.7 \mathrm{eV})$. The 10 at.\% $\mathrm{Cu}$ layer promotes oxidation of $\mathrm{Si}$ catalyzed by $\eta-\mathrm{Cu}_{3} \mathrm{Si}$. The microstructures also indicate that $\mathrm{Si}$ implanted with $\sim 2$ at.\% $\mathrm{Cu}$ reforms epitaxially with embedded defects after $8 \mathrm{hr}$. at $700^{\circ} \mathrm{C}$, but for $\sim 10$ at. $\% \mathrm{Cu}$, epitaxy is not recovered after 6 hours at $600^{\circ} \mathrm{C}$.
\end{abstract}

\section{INTRODUCTION}

Advanced Si devices often require high purity to perform properly. The transition metals are an important class of detrimental impurities in $\mathrm{Si}$ [1], for which impurity levels $<1 \times 10^{8} / \mathrm{cm}^{3}$ are projected to be required. We have examined $\mathrm{Cu}$ as an example, and used ion-implantation to characterize its binding on the walls of cavities in Si formed by prior implantation of He to greater depths [2-4]. Here, microstructures of the implanted layers as determined with transmission electron microscopy (TEM) at $200 \mathrm{keV}$, and with Rutherford backscattering spectroscopy (RBS) are presented to evaluate the transport of $\mathrm{Cu}$ to the cavities properly. At low concentrations $(<1.2$ at.\%) $\mathrm{Cu}$ is bound to defects in the layer that inhibit its transport, but at 10 at.\%, $\eta-\mathrm{Cu}_{3} \mathrm{Si}$ forms, allowing $\mathrm{Cu}$ diffusion into $\mathrm{Si}$ at its equilibrium solid solubility. Knowing the precipitation and solution behavior of the $\mathrm{Cu}$ has allowed us to determine that the cavities bind it more strongly $(2.2 \mathrm{eV}$ w.r.t. solution) than does $\mathrm{Cu}$ silicide $(1.7 \mathrm{eV})[3,4]$. Moreover, cavity trapping is more effective than silicide precipitation gettering mechanisms currently in use [5] since it is expected to operate at concentrations far below the solid solubility.

Copper is also being evaluated as a possible new metallization for Si microelectronic devices [6]. That application would increase the importance of effective gettering and the need to understand the reactions occuring ${ }^{2}$ ith $\mathrm{Cu}$ on the surface of $\mathrm{Si}$. We find that $\mathrm{Cu}$ implantation to 10 at.\% promotes rapid oxidation of $\mathrm{Si}$. We identify $\eta-\mathrm{Cu}_{3} \mathrm{Si}$ at the oxide/Si interface, which implies that it catalyzes the oxidation, as discussed by others $[7,8]$. The microstructures also indicate that the amorphous layer existing after implantation crystallizes and reforms epitaxially with embedded defects at for 1.2 at. $\% \mathrm{Cu}$, but epitaxy was not recovered at $600^{\circ} \mathrm{C}$ for 10 at. $\%$.

\section{LOW Cu CONCENTRATIONS}

Specimens of (100) Si were first implanted with $1 \times 10^{17} \mathrm{He} / \mathrm{cm}^{2}$ at $100 \mathrm{keV}$ and annealed $1 / 2$ hour at $700^{\circ} \mathrm{C}$ to form cavities at a depth of $0.3 \mu \mathrm{m}$ and outgas the He [9]. Specimens were then implanted with $1 \times 10^{16} \mathrm{Cu} / \mathrm{cm}^{2}$ at $150 \mathrm{keV}$, which gave a peak concentration of 2.5 at. $\%$ at $74 \mathrm{~nm}$. Annealing for 8 hours at $700^{\circ} \mathrm{C}$ reduced the peak to 1.2 at. $\% \mathrm{Cu}$, which still greatly exceeds the solid solubility of $\mathrm{Cu}\left(2 \times 10^{-5}\right.$ at.\%) [10], and trapped $0.5 \times 10^{16} \mathrm{Cu} / \mathrm{cm}^{2}$ at the deeper

$$
\text { MASTP }
$$




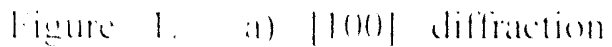
pattern from si implanted with

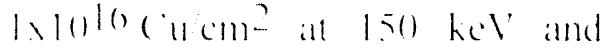
ambated 1.2 hour al $7000^{\circ}$. shoming mo a and h rellections. h) Brightiche image of defects: arroms shom the and gyos.
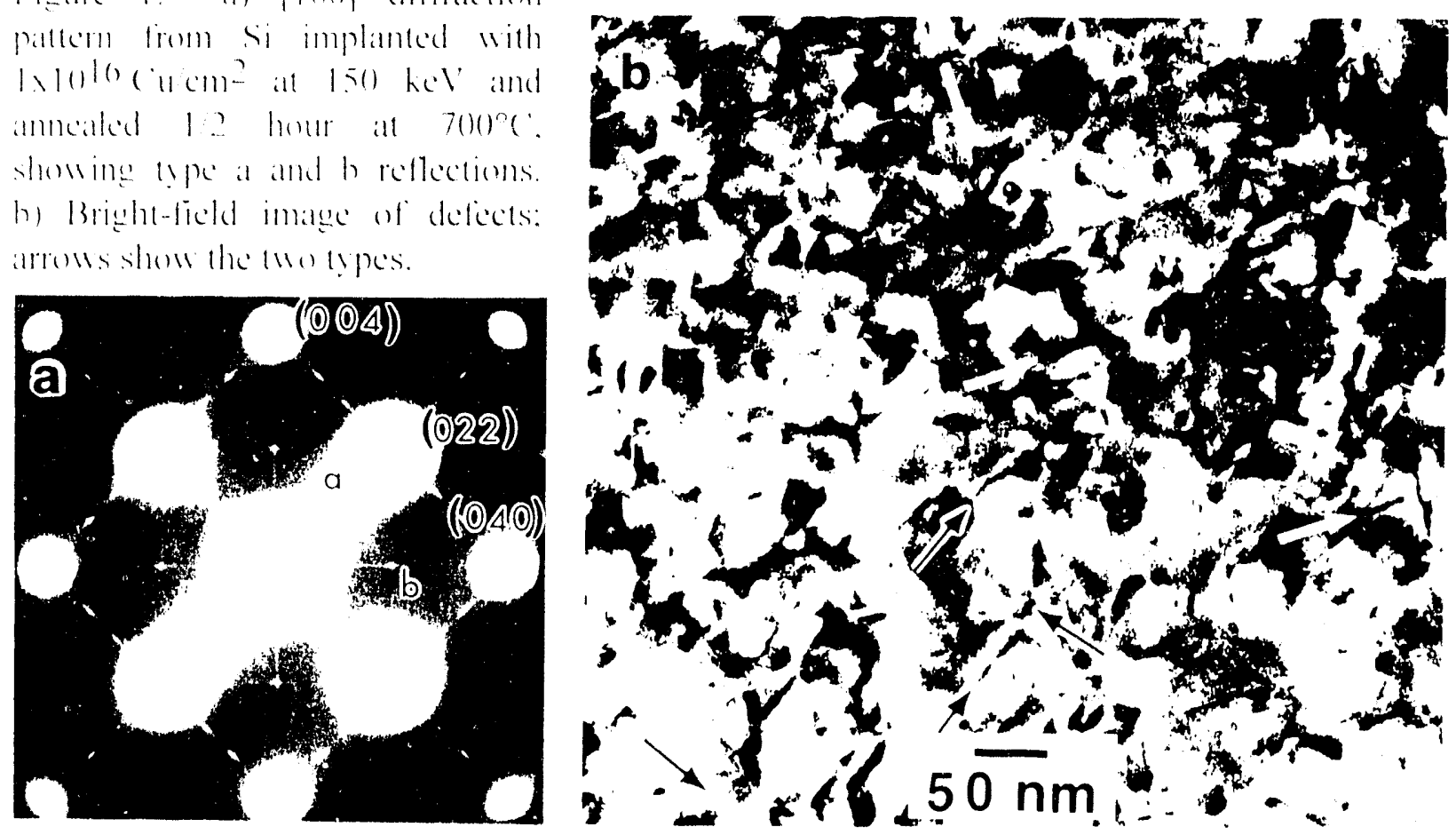

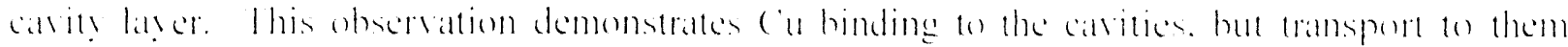

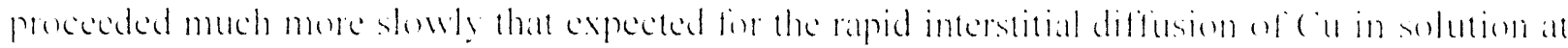

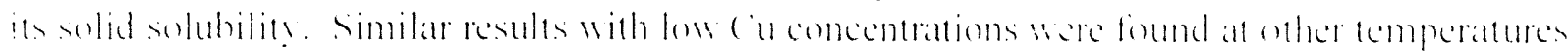

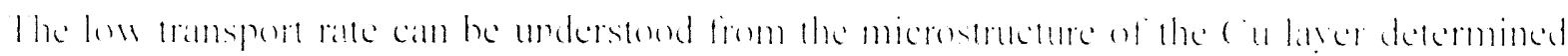

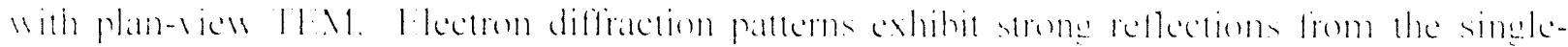

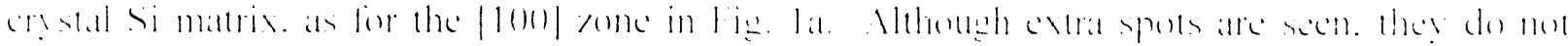

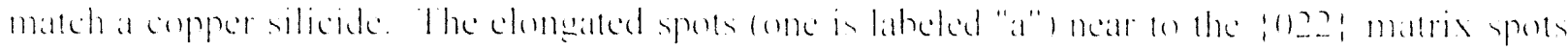

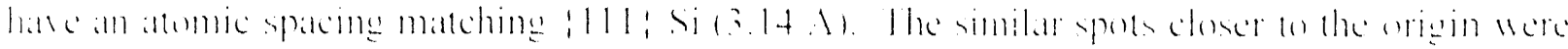

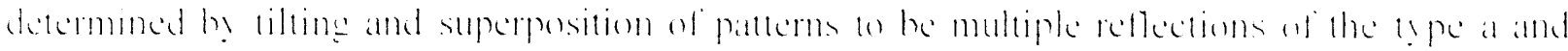

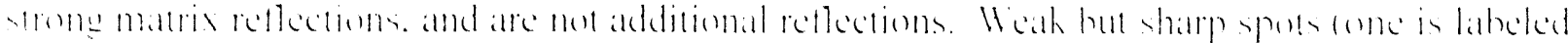

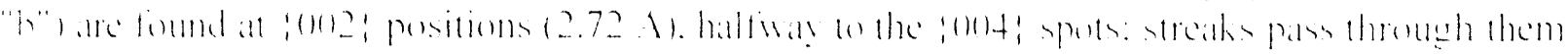

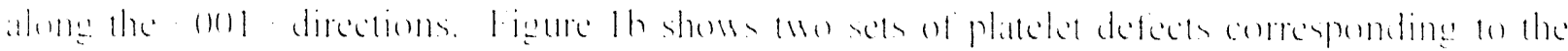

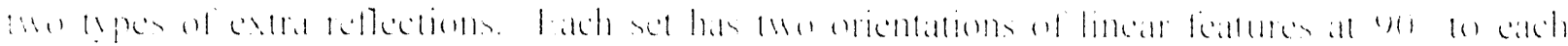

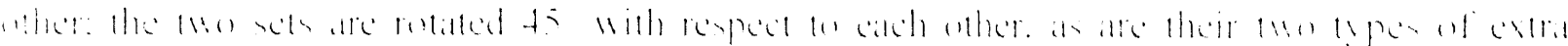

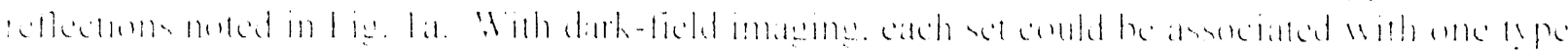

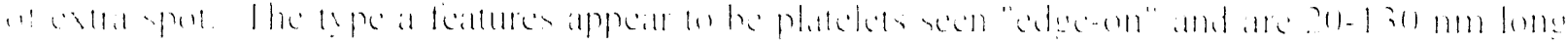

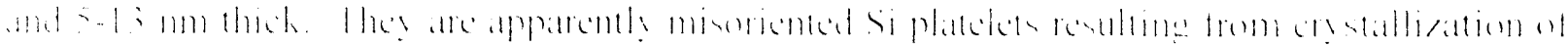

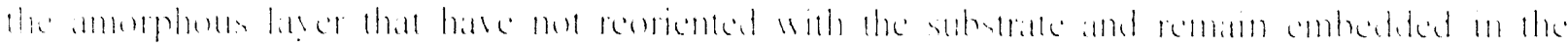

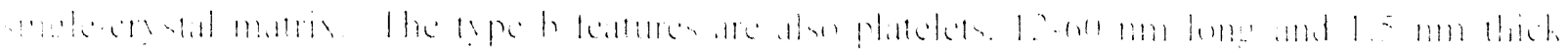

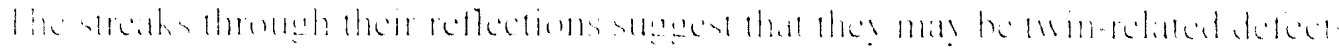

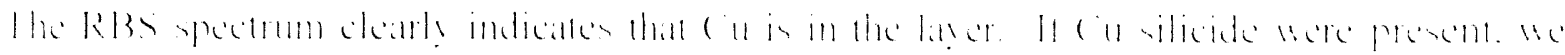

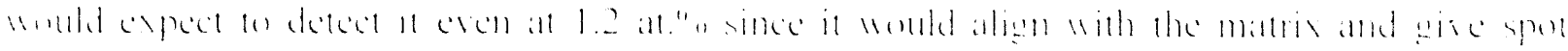

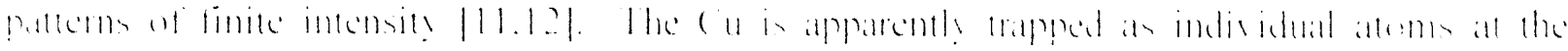

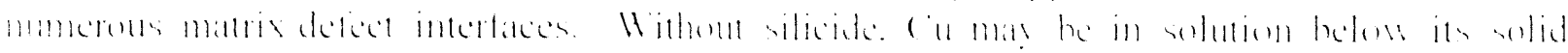

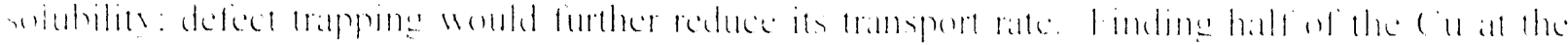

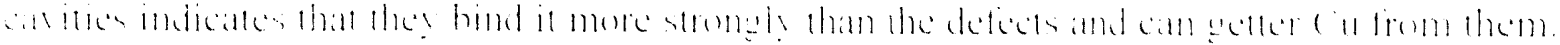




\section{HIGH Cu CONCENTRATIONS}

A second type of (100) Si specimen was prepared by increasing the fluence to $1 \times 10^{17} \mathrm{Cu} / \mathrm{cm}^{2}$ at $150 \mathrm{keV}$. In these specimens, $\mathrm{Cu}$ diffused to cavity traps at a rate consistent with its diffusivity and solubility in Si until they saturated. After annealing 6 hours at $600^{\circ} \mathrm{C}$, the $\mathrm{Cu}$ profile peaked at 10 at. $\%$ at a depth of $62 \mathrm{~nm}$. Initially, specimens were stored in ambient air and appeared "hazy" to the eye within a day after annealing or $\sim 3$ days without annealing. The haze appeared more slowly in similar (111) specimens, e.g. $\sim 20$ days. The haze is due to Si-O particles on the surface. The particles are $0.1-0.2 \mu \mathrm{m}$ as seen in the secondary electron image in Fig. 2, obtained with the TEM's scanning unit. The microdiffraction pattern in Fig. $2 \mathrm{~b}$ from a large particle suspended over a hole in the thinned specimen has broad, diffuse rings indicating amorphous material. Other particles have areas that change contrast during tilting and sharp spots superimposed on the ring pattern, indicating that they contain crystallites. Energy dispersive characteristic $x$-ray spectra from suspended particles showing no crystallites gave spectra with strong $\mathrm{Si}$ and $\mathrm{O}_{\alpha}$ peaks and almost no $\mathrm{Cu}$; the $\mathrm{C}_{\alpha}$ peak was detected, apparently due to beam contamination. Thus the particles are amorphous silicon oxides. Such particles are not present on any of our other Si samples, only those implanted with high fluences of $\mathrm{Cu}$.

Electron diffraction analysis identifies the material between particles as polycrystalline Si and $\eta-\mathrm{Cu}_{3} \mathrm{Si}$. A pattern from a thin area is shown in Fig. 3. Phase analysis is done first by excluding the rings of randomly oriented Si (arrowed); Table I lists the atomic spacings measured for the remaining rings along with those of matching phases in column 1. Identification of the silicide is complicated by two ordering transformations expected as $\eta-\mathrm{Cu}_{3} \mathrm{Si}$ cools from $600^{\circ} \mathrm{C}$ to room temperature $\left(\eta \rightarrow \eta \eta^{\prime} \rightarrow \eta^{\prime \prime}\right)$ [13]. Solberg [11] examined electron diffraction patterns of room temperature $\eta "$ and deduced a large, ordered orthorhombic unit cell $(76.76 \AA .7 .00 \AA, 21.94 \AA)$. His single-crystal patterns imply very many rings but with unknown intensities. A key to the identification is noted by Weber et al. [12]: Solberg's structure has a hexagonal sublattice that accounts for strong reflections. They fit their and Solberg's data to obtain a $=4.04 \AA, \mathrm{c}=2.44 \AA$.

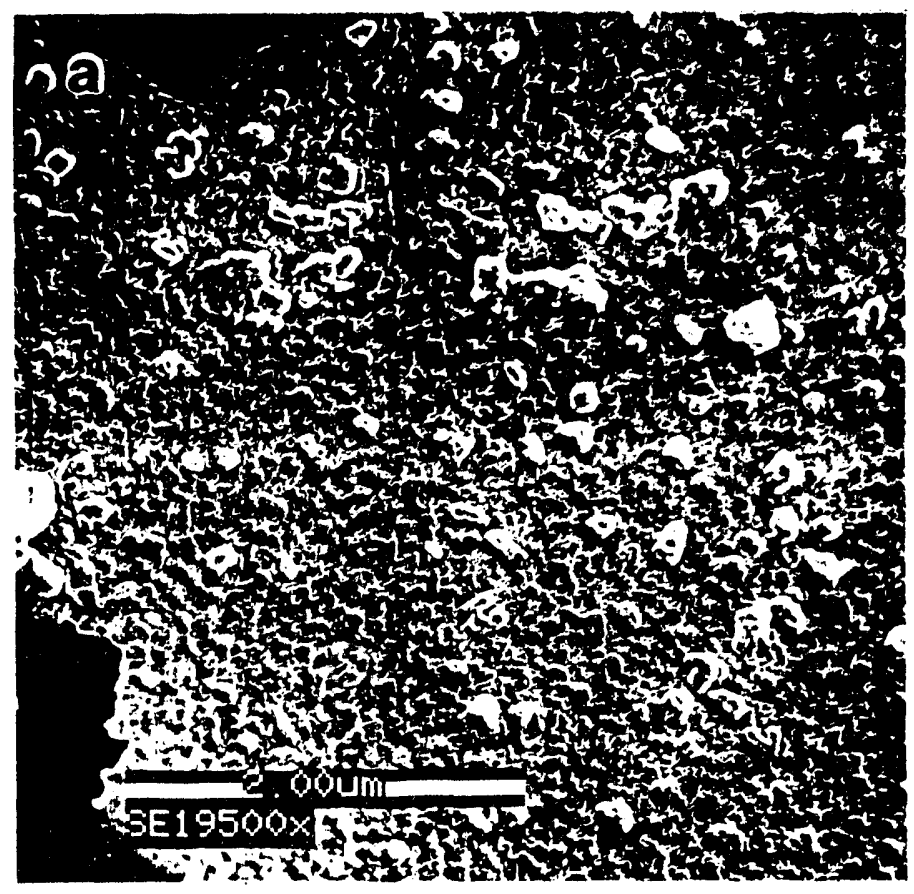

Figure 2. a) Secondary electron image of oxides on (100) $\mathrm{Si}$ implanted with $1 \times 10^{17} \mathrm{Cu} / \mathrm{cm}^{2}$ at $150 \mathrm{keV}$ and annealed 6 hours at $600^{\circ} \mathrm{C}$. b) Diffraction pattern from an oxide particle (two exposures).

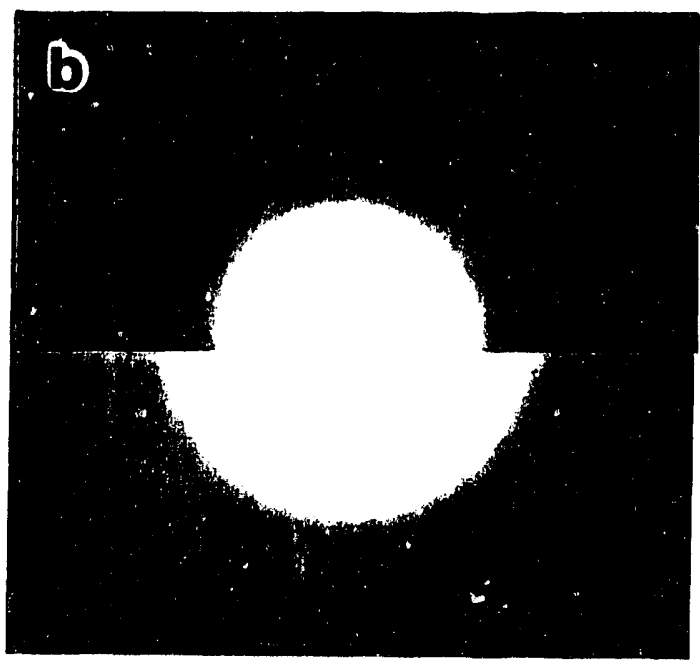




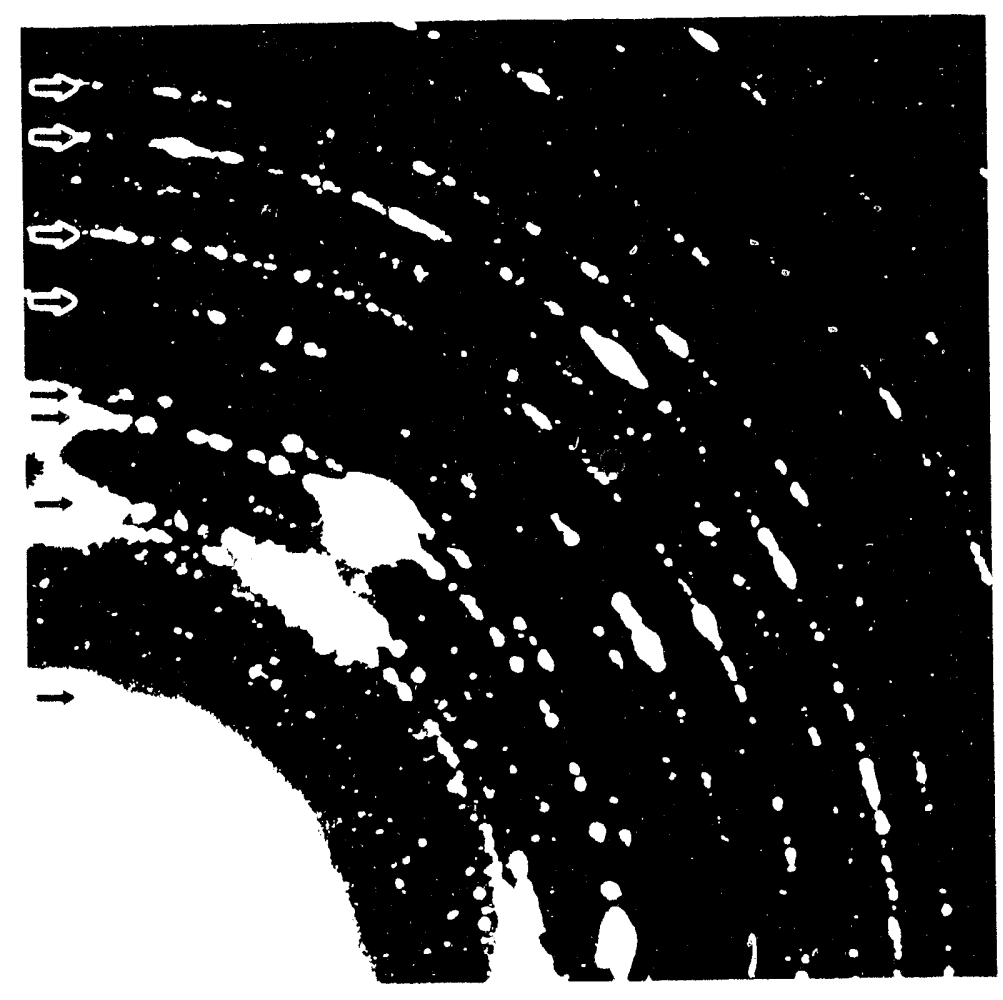

ligure $\quad$ 1 ketrom difleation paltem trom thin area of si implanted mith

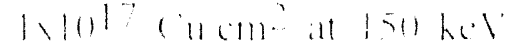
and ammolled lon 6 hours all

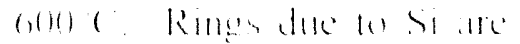

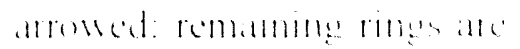
lisket in lakk.

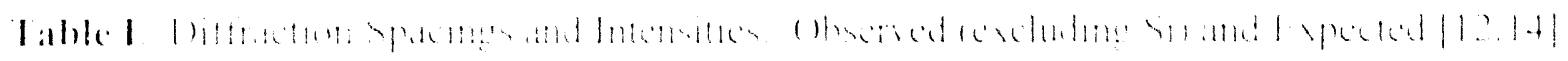

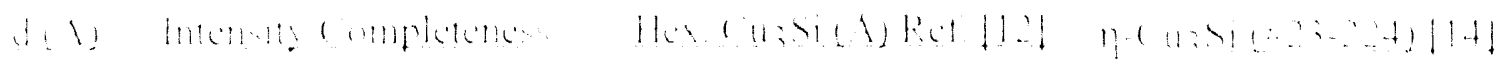

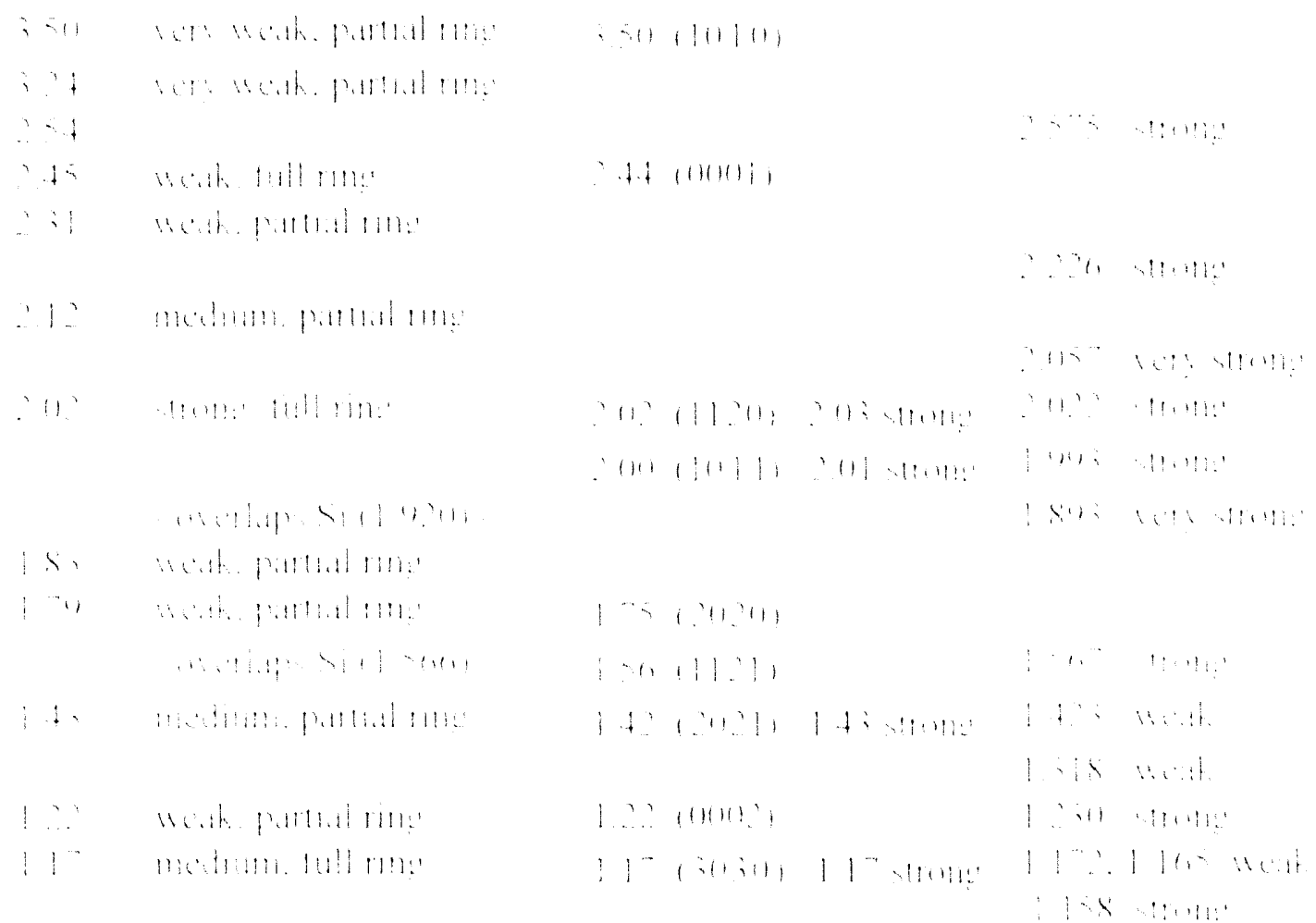

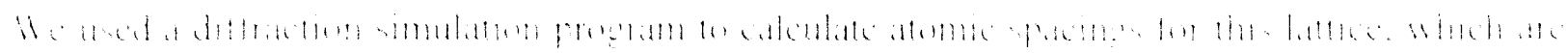

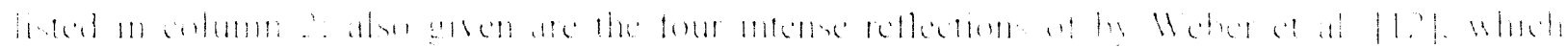


match our most intense rings. The hexagonal lattice accounts for the prominent rings and some less intense ones, as well as others reported earlier [14] (column 4). Atomic ordering apparently produces the additional reflections in column 1 . On this basis we conclude that $\eta-\mathrm{Cu}_{3} \mathrm{Si}$ (or related $\eta^{\prime}$ or $\left.\eta^{\prime \prime}\right)$ has formed in the implanted layer. Diffraction patterns from thicker areas show the [100] Si zone and the "type a" spots seen with the lower $\mathrm{Cu}$ concentration in Fig. $1 \mathrm{a}$.

The nature of the polycrystalline layer and the role of $\eta-\mathrm{Cu}_{3} \mathrm{Si}$ in oxidation are more apparent from cross-section images like Fig. $4 \mathrm{a}$. This specimen was kept under high vacuum $\left(<5 \times 10^{-7}\right.$ torr) except during thinning for TEM. Nonetheless, amorphous oxide particles protrude above and extend beneath the surface. Between them, the layer has a well-defined depth, $0.25 \mu \mathrm{m}$, with lateral crystal sizes 0.1-0.6 $\mu \mathrm{m}$; some crystals exhibit twinning. A defected region beneath the layer exhibits strain contrast in other images. The Si grains dominate the images and make identifying specific $\mathrm{Cu}_{3} \mathrm{Si}$ grains difficult. Identifying silicide grains within the layer is complicated by the many boundaries and overlapping crystals that give multiple diffraction. However, $\eta-\mathrm{Cu}_{3} \mathrm{Si}$ particles can be identified at the edges of the oxides. Tilting them into contrast and diffracting from a $1 / 4 \mu \mathrm{m}$ diameter selected area gave patterns with spots indexing to $\eta-\mathrm{Cu}_{3} \mathrm{Si}$ reflections in Table I but not Si. A row of spots in Fig. 4b matches $(10 \overline{1} 0),(20 \overline{2} 0)$ and $(30 \overline{3} 0)$ in the hexagonal notation. Dark-field imaging with these spots illuminates silicide particles around the edge of the oxide particle, as seen in inset Figs. $4 \mathrm{c}$ and $4 \mathrm{~d}$. Note that this silicide was carried beyond the original layer depth by the oxide growth. Finding $\eta$-Cu3 $\mathrm{Si}$ at the oxide/Si interface means that it can promote oxidation as well as furnish $\mathrm{Cu}$ into solution in substrate. However, the amount of $\mathrm{Cu}_{3} \mathrm{Si}$ at these interfaces is less than expected for $10 \mathrm{at} . \% \mathrm{Cu}$. Additional silicide apparently lies within the polycrystalline layer.

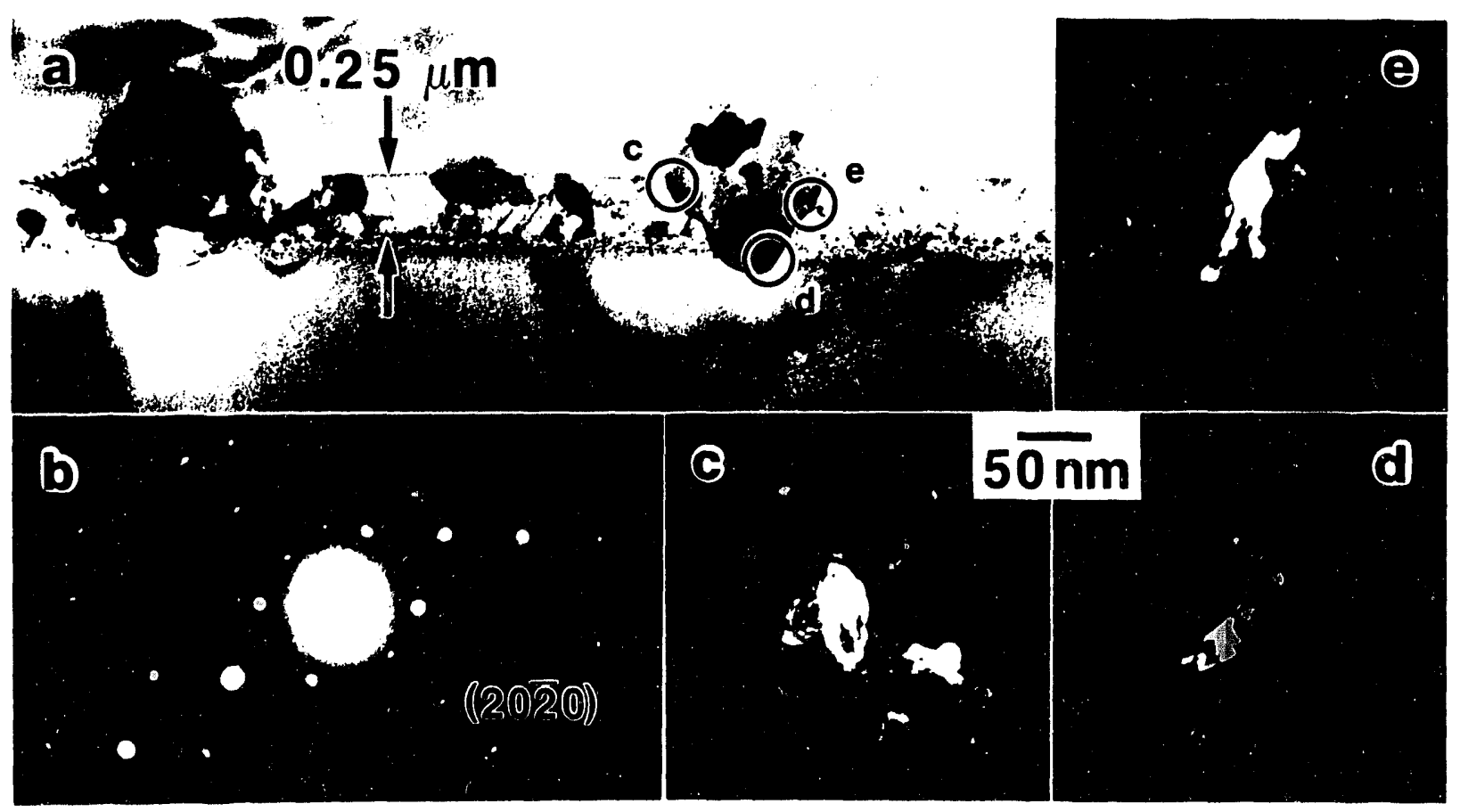

Figure 4. a) [011] Bright-field cross-section TEM image of (100) Si implanted with 10 at.\% $\mathrm{Cu}$, showing oxide particles growing inward from the surface. b) Electron diffraction pattern from grain in c) identifying its as $\eta-\mathrm{Cu}_{3} \mathrm{Si}$. c), d) and e) Dark-field images of $\eta-\mathrm{Cu}_{3} \mathrm{Si}$ grains around $\mathrm{Si}-\mathrm{O}$ particle, in areas indicated correspondingly in a). 


\section{SUMMARY AND CONCLUSIONS}

Implantation of $\mathrm{Cu}$ into $\mathrm{Si}$ followed by annealing at $600^{\circ} \mathrm{C}$ results in $\eta-\mathrm{Cu}_{3} \mathrm{Si}$ formation provided the $\mathrm{Cu}$ concentration is high enough $(\sim 10$ at.\%). Its presence is consistent with the transport rates of $\mathrm{Cu}$ to internal cavities and allows its binding energy to the silicide phase to be evaluated, $1.7 \mathrm{eV} /$ atom, which is less than the binding energy to cavity walls, $2.2 \mathrm{eV} /$ atom. The silicide was not seen at lower concentration (1.2 at.\%), where defect trapping is inferred to have inhibited $\mathrm{Cu}$ transport to the cavities. The high concentration blocks epitaxial regrowth, giving a polycrystalline surface layer with twinning. The $\eta-\mathrm{Cu}_{3} \mathrm{Si}$ catalyzes rapid oxidation of Si through the layer and into the substrate during exposure to air at room temperature. The phase is probably initially present at the surface since RBS indicates a surface concentration of 4.3 at.\% $\mathrm{Cu}$. We find silicide particles carried into the $\mathrm{Si}$ substrate during oxidation, as reported by others $[8,15]$. Visual examination indicates that (100) surfaces oxidize faster than (111), in agreement with other work [7,8]. If $\mathrm{Cu}$ is used as a metallization for $\mathrm{Si}$ microcircuits, it needs to have effective barriers that prevent its reacting with the $\mathrm{Si}$.

\section{ACKNOWLEDGEMENTS}

The authors thank M. P. Moran and K. Schleher for assistance with the TEM investigation and D. M. Bishop for performing the implantations and RBS analyses. Discussions with J. W. Mayer and $\mathrm{T}$. Alford on the oxidation of $\mathrm{Si}$ by $\mathrm{Cu}_{3} \mathrm{Si}$ and $\mathrm{J}$. Custer on amorphous Si regrowth were very helpful. This work was supported by the U.S. Dept. of Energy under Contract DE-AC0494AL85000 and partly funded its Office of Basic Energy Sciences, Materials Science Division.

\section{REFERENCES}

1. H. Huff, Fourth Intl. Symp. on ULSI, eds. G. Celler, E. Middlesworth and K. Hoh (Electrochemical Society, Pennington, NJ, 1993).

2. S. M. Myers, H. J. Stein, W. R. Wampler and D. M. Follstaedt, Mat. Res. Soc. Symp. Proc. 283, 549 (1993).

3. S. M. Myers, D. M. Follstaedt and D. M. Bishop, Proc. 17 th International Conference on Defects in Semiconductors, to be published.

4. S. M. Myers, D. M. Follstaedt and D. M. Bishop, this volume.

5. W. Schröter, M. Seibt and D. Gilles, in Materials Science and Technology, ed. W. .Schröter, (VCH Publishers, New York, 1991) 4, p. 539-589.

6. MRS Bulletin 13, No. 6 (June 1993) has several articles on Cu metallizations.

7. J.M. Harper, A. Charai, L. Stoltz. F.M. d'Heurle, P. Fryer, Appl. Phys. Lett. 56, 2519 (1990).

8. T. L. Alford, D. Adams, J. Li, B. Cao, S.W. Russel, S.Q. Hong, R. Spreitzer and J.W. Mayer, Fall, 1993 MRS Meeting, Proc. Symp. D: Silicides, Germanides and their Interfaces.

9. C.C. Griffioen, J.H. Evans, P.C. De Jong and A. Van Veen, Nucl. Inst. Meth. 27, 417 (1987).

10. R.C. Dorward and J. S. Kirkaldy. Trans Met. Soc. AIME 242, 2055 (1968).

11. J. K. Solberg, Acta Cryst. A 34, 684 (1978).

12. G. Weber, B. Gillor and P. Barret. Phys. Stat. Sol. (a) 75, 567 (1983).

13. R. W. Olesinski and G. J. Abbaschian, in Binary Alloy Phase Diagrams, eds. T. B. Massalski, J. L. Murray, L.H. Bennett and H. Baker (ASM, Metals Park, OH, 1986) Vol. 1, 960 (Cu-Si).

14. K. P. Mukherjee, J. Bandyopadhyaya and K. P. Gupta, Trans. Met. Soc. 245, 2335 (1993).

15. J. Li, J. W. Mayer, L. J. Matienzo and F. Emmi, Mat. Chem. Phys. 32, 390 (1992). 


\section{DISCLAIMER}

This report was prepared as an account of work sponsored by an agency of the United States Government. Neither the United States Government nor any agency thereof, nor any of their employees, makes any warranty, express or implied, or assumes any legal liability or respons:bility for the accuracy, completeness, or usefulness of any information, apparatus, product, or process disclosed, or represcnts that its use would not infringe privately owned rights. Reference herein to any specific commercial product, process, or service by trade name, trademark, manufacturer, or otherwise does not necessarily constitute or imply its endorsement, recommendation, or favoring by the United States Government or any agency thereof. The views and opinions of authors expressed herein do not necessarily state or reflect those of the United States Government or any agency thereof. 

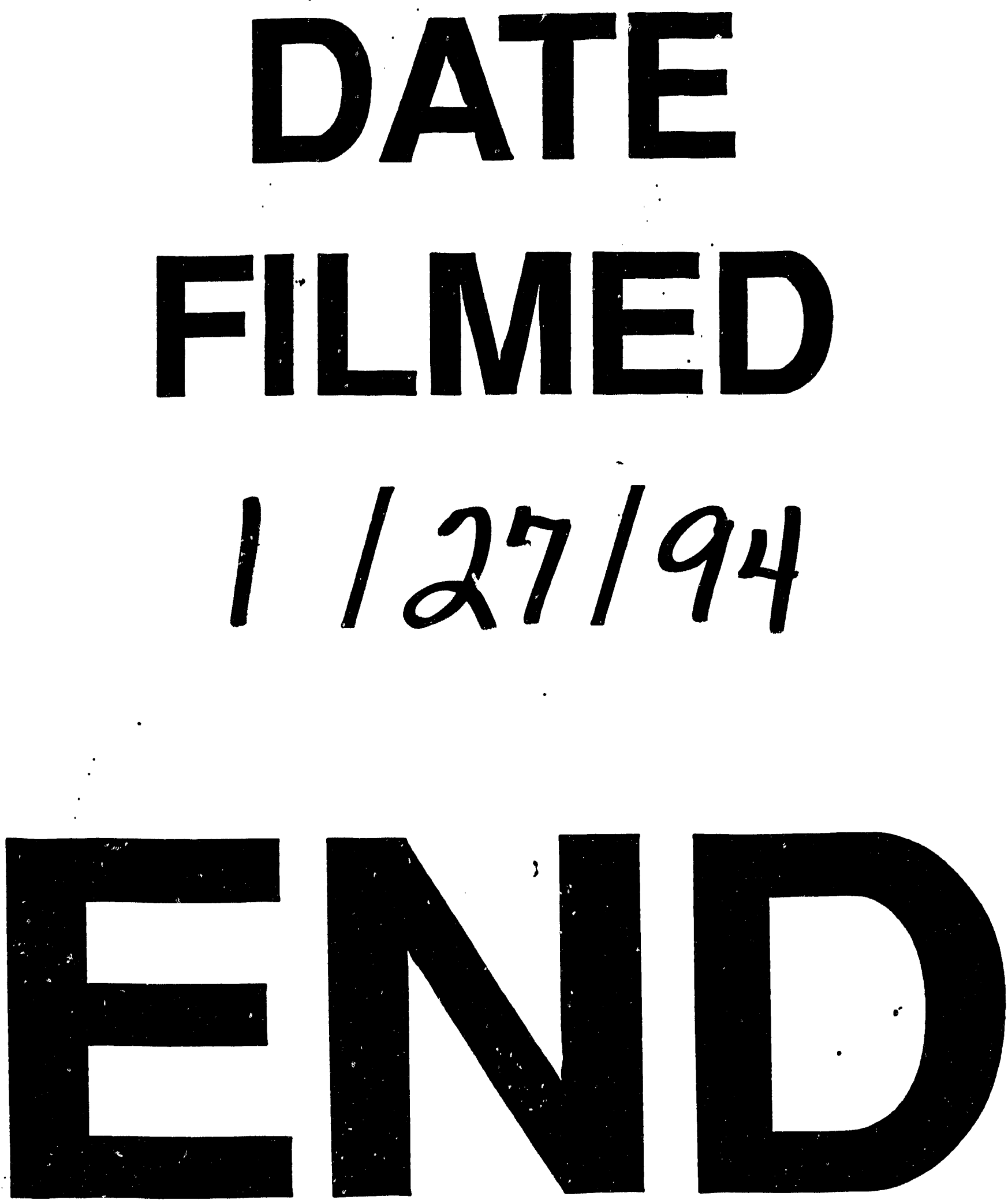
